\title{
PENGGUNAAN SOFTWARE GEOGEBRA DALAM MENINGKATKAN KEMAMPUAN MATEMATIS SISWA PADA PEMBELAJARAN GEOMETRI DI SMPN2 TANJUNG MORAWA
}

\author{
Antonius KAP Simbolon \\ Universitas Prima Indonesia \\ antoniussimbolon8@gmail.com
}

\begin{abstract}
Learning geometry has not paid attention to aspects of mathematical ability with maximum so that learning outcomes are also not optimal. Technology has been developing with one of them is the emergence of geogebra software version 6.0 which can help the process learning mathematics but not yet utilized in learning. This research aims to determine the magnitude of the increase in activity and learning achievement in mathematics on geometry using geogebra software. This research was conducted in SMPN 2 Tanjung Morawa, Class IX with 210 students. The method used is action class research method consists of two cycles. The analysis used in this research is comparative descriptive analysis by comparing data between the cycles. Geogebra is used to visualize the geometry object to be transformed. Through a visualization process, students try, reason, and finally can find the concept of transformation. The result shows an increase in student activity during the learning. Test results for each cycle shows an increase in the number of students who reach the minimum completeness (KKM). On the condition of the end of the cycle of students who are complete in learning reaches $85,24 \%$. Based on this then learning by using geogebra software can improve abilities mathematical.
\end{abstract}

Keywords: Geometry, Geogebra, Mathematical Ability

\begin{abstract}
Abstrak
Penelitian ini bertujuan untuk mengetahui besarnya peningkatan keaktifan dan prestasi belajar matematika pada materi geometri menggunakan software geogebra. Penelitian ini dilaksanakan di kelas IX SMP Negeri 2 Tanjung Morawa yang berjumlah 210 siswa. Metode yang digunakan adalah metode penilitian tindakan kelas yang terdiri dari dua siklus, analisis yang digunakan adalah deskriptif komparatif dengan membandingkan data antar siklus. Adapun indikator kemampuan matematis siswa dilihat dari hasil belajar nya, apakah terdapat perubahan kemampuan matematis siswa sebelum dan sesudah menggunakan software Geogebra dalam pembelajaran geometri. Geogebra digunakan untuk memvisualisasikan obyek geometri yang akan ditransformasikan. Melalui proses visualisasi siswa mencoba, menalar, dan akhirnya dapat menemukan konsep transformasi. Hasil penelitian menunjukkan adanya peningkatan keaktifan siswa selama pembelajaran. Hasil tes setiap siklus menunjukkan adanya kenaikan jumlah siswa yang mencapai ketuntasan minimal (KKM). Pada kondisi akhir siklus siswa yang tuntas dalam belajar mencapai $85,24 \%$. Berdasarkan hal ini maka pembelajaran dengan menggunakan software geogebra dapat meningkatkan kemampuan matematis.
\end{abstract}

Kata Kunci: Geometri, Geogebra, Kemampuan Matematis

\section{PENDAHULUAN}

Dalam menghadapi tantangan zaman revolusi industri 4.0 diperlukan adanya peningkatan sumber daya manusia sehingga kita dapat bersaing dalam ranah internasional. Salah satu bidang yang dapat kita gunakan sebagai jembatan untuk meningkatkan sumber daya manusia yang berkualitas adalah dalam dunia pendidikan. Salah satu cabang ilmu pengetahuan yang memegang peranan penting dalam dunia pendidikan adalah matematika. Matematika sebagai salah satu bidang dalam pembelajaran di sekolah merupakan bidang yang mendapat perhatian dalam pengembangan pembelajarannya. Mata pelajaran matematika di SMP misalnya yang cenderung abstrak. Hal ini menyebabkan matematika merupakan salah satu mata pelajaran yang dianggap sulit bagi siswa. Salah satu bagian dari matematika yang bersifat abstrak adalah geometri (Pamungkas et al., 2020). 
Tertulis dalam Peraturan Menteri Pendidikan Nasional No. 16 Tahun 2007 ditegaskan bahwa salahsatu kompetensi pedagogik yang harus dimiliki guru mata pelajaran matematika SMP/MTs adalah mampu memanfaatkan teknologi informasi dan komunikasi untuk kepentingan pembelajaran. Sementara untuk kompetensi profesionalnya guru harus mampu memanfaatkan Teknologi Informasidan Komunikasi (TIK) untuk berkomunikasi dan mengembangkan diri. Penerapan utama dari teknologi dalam pembelajaran Matematika adalah adanya pengintegrasian perangkat lunak (software) untuk pembelajaran Matematika. Hal ini yang menyebabkan banyak perangkat lunak yang dikembangkan dan dimanfaatkan (Peraturan Menteri Pendidikan Nasional Republik Indonesia Nomor 16 Tahun 2007, 2007).

Menurut Dahal (2019), matematika secara umum didefenisikan sebagai bidang ilmu yang mempelajari pola struktur, perubahan dan ruang kehidupan, karena dalam setiap aktivitas sehari-hari, didasari atau tidak kita pasti menggunakan matematika. Matematika membekali siswa untuk mempunyai sistematis, kritis dan kreatif oleh karena itu matematika menjadi harus dikuasai oleh setiap orang (Dahal \& Thapa, 2019).

Namun berdasarkan laporan TIMMS 2011 siswa kelas IX Indonesia menempati posisi ke 38 diantara 42 negara yang berpartisipasi dalam tes matematika dengan skor rata-rata 406 sedangkan skor standar rata-rata internasional adalah 500. Hasil survey TIMMS tentang kemampuan matematis siswa Indonesia ternyata tidak jauh berbeda dengan hasil survey dari lembaga lain seperti PISA (Programme International for Student Assesment). Berdasarkan hasil survey PISA 2012, kemampuan matematis siswa Indonesia menempati ranking 64 dari 65 negara dengan rata-rata skor yang diperoleh 375, sedangkan rata-rata skor internasional yang ditetapkan PISA adalah 494 (Bawono, 2015).

Domain konten soal yang diteskan PISA kepada siswa di Indonesia salah satunya adalah geometri. Sub-sub komponen konten yang diteskan yaitu perubahan dan keterkaitan, ruang dan bentuk, kuantitas, ketidakpastian dan data (Safrida et al., 2018). Banyak persoalan geomerti yang memerlukan visualisasi dalam pemecahan masalah dan pada umumnya siswa merasa kesulitan dalam mengkonstruksi bangun ruang geometri, seperti yang dialami para siswa di SMPN 2 Tanjung Morawa. Salah satu upaya memvisualisasikan ide-ide matematika agar matematika bisa dipahami oleh siswa, khususnya pada materi geometri, dibutuhkan suatu strategi pembelajaran yang lebih inovatif. Diantaranya adalah media inovatif dengan pemanfaatan kemajuan Teknologi Informasi dan Komunikasi (TIK) dalam bentuk media geogebra sebagai sumber belajar maupun media pembelajaran.

Di kelas Matematika, penggunaan teknologi membantu peserta didik dan guru untuk melakukan perhitungan yang lebih baik, menganalisis data dan meningkatkan eksplorasi konsep matematika, sehingga menghasilkan permanen dan pembelajaran yang efektif dalam Matematika. Karena TIK penting dalam lingkungan pendidikan, maka perlu menggunakan teknologi yang lebih menguntungkan untuk belajar matematika secara komprehensif. Integrasi teknologi dalam pendidikan 
matematika terutama dilakukan melalui penggunaan komputer di lingkungan belajar (Adelabu et al., 2019).

Menurut Saputra (2019), selama ini pembelajaran geometri di kelas hanya diajarkan menggunakan media papan tulis dan belum memanfaatkan media pembelajaran seperti komputer. Penyampaian materi yang sering dilakukan guru adalah berupa pembelajaran konvensional seperti ceramah, sehingga ada siswa yang mengalami kesulitan untuk memahami materi yang disampaikan (Saputra \& Fahrizal, 2019). Untuk itu dibutuhkan media lain yang dapat membantu pemahaman siswa mengenai geometri tersebut.

Salah satu media pembelajaran matematika berbasis teknologi yang dapat membantu siswa dalam merepresentasikan permasalahan matematika adalah software GeoGebra. Salah satu media pembelajaran yang dapat merepresentasikan model matematika atau merepresentasikan persamaan linier dua variabel ke dalam bentuk grafik yaitu dengan menggunakan bantuan media software GeoGebra. Menurut Japa (2017), GeoGebra adalah software matematika dinamis yang menggabungkan geometri, aljabar, dan kalkulus (Japa et al., 2017).

Sedangkan menurut Ekawati (2016), GeoGebra adalah software matematika yang mudah digunakan, baik pada materi geometri, aljabar, dan kalkulus (Ekawati, 2016). Dari beberapa pengertian GeoGebra diatas dapat disimpulkan bahwa GeoGebra merupakan salah satu software matematika yang dapat digunakan dalam pembelajaran matematika yang meliputi materi geometri, aljabar, dan kalkulus. GeoGebra berfungsi sebagai media pembelajaran matematika yang dapat membantu siswa secara visual untuk memahami materi matematika yang besifat abstrak.

Tidak hanya itu GeoGebra juga dapat membantu siswa dalam memahami konsep grafik garis lurus secara lebih rinci dengan tampilan yang variatif dan menarik. Selain itu bagi guru sendiri, GeoGebra dapat digunakan sebagi alat bantu pembelajaran matematika untuk menciptakan pembelajaran yang interaktif yang memungkinkan siswa mengeksplorasi berbagai konsep-konsep matematika bersifat abstrak (Muqtada et al., 2018).

Selanjutnya menurut Sari (2018) “Computer algebra systems, dynamic geometry software, and spreadsheetsare the main types of educational software currently used for mathematicsteaching and learning. Each of the programs has its own advantages and isespecially useful for treating a certain selection of mathematical topics orsupports certain instructional approaches" (Sari et al., 2018).

Software Geogebra adalah salah satu produk teknologiyang saat ini banyak dimanfaatkan dalam pembelajaran matematika. Software ini banyak dimanfaatkan sebagai alat bantu untuk mengonstruksi, mendemonstrasikan atau memvisualisasikan masalah abstrak pada matematika yang tidak dapat diselesaikan secara manual khususnya pada bidang geometri (Saputro, 2016).

Berdasarkan pemaparan latar belakang masalah maka didapatkan rumusan masalah pada kegiatan penelitian ini yaitu, apakah penggunaan media software GeoGebra dapat meningkatkan kemampuan matematis siswa SMP kelas IX. Dari rumusan masalah diatas, maka tujuan dari kegiatan 
penelitian ini adalah untuk mengetahui apakah penggunaan media software GeoGebra dapat meningkatkan kemampuan matematis siswa SMP Negeri 2 Tanjung Morawa kelas IX.

\section{METODE}

Indikator peningkatan kemampuan matematis siswa dalam penelitian adalah dengan melihat hasil belajar siswa dalam pembelajaran geometri sebelum dan sesudah menggunakan software Geogebra. Metode Penelitian ini merupakan penelitian tindakan kelas (Classroom Action Research). Subyek penelitian adalah siswa kelas IX semester 1 tahun pelajaran 2020/2021 sebanyak 210 siswa. Data yang diteliti dalam penelitian tindakan kelas ini adalah ketuntasan belajar siswa dan kemampuan matematis siswa dalam proses pembelajaran. Data dikumpulkan dengan menggunakan teknik dokumentasi dari hasil pretest sebagai kondisi awal. Ketuntasan belajar diperoleh dari kemampuan matematis siswa dalam menyelesaikan soal geometri melalui tahapan tes siklus I dan siklus II.

Data yang sudah dikumpulkan kemudian dianalisis dengan menggunakan dua cara yaitu: data kuantitatif hasil belajar dianalisa dengan deskriptif komparatif yaitu membandingkan nilai hasil belajar pada kondisi awal, siklus I, dan siklus II. Data kualitatif proses pembelajaran sebagai gambaran presentase siswa dalam kemampuan matematis siswa dianalisa dengan deskriptif kualitatif. Data kualitatif dibandingkan antara kondisi awal, siklus I, dan siklus II. Prosedur penelitian dapat dilihat pada Gambar 1.

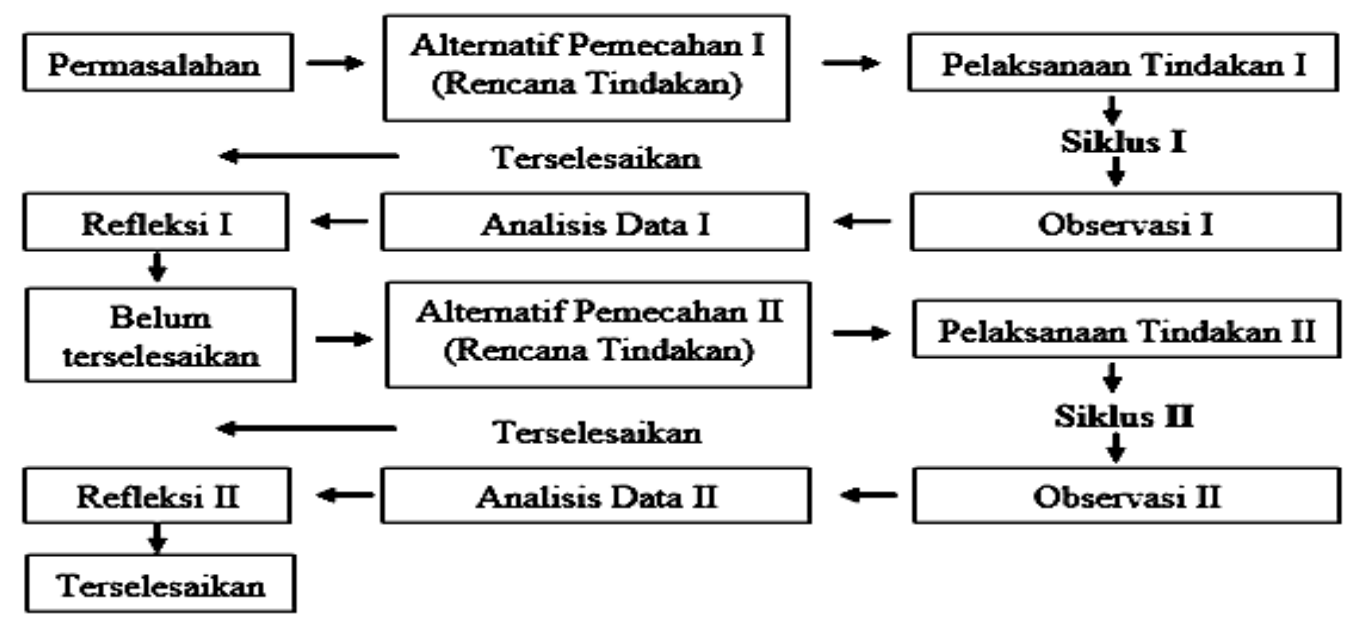

Gambar 1. Diagram Prosedur Penelitian

Berdasarkan gambar 1 menunjukkan bahwa proses penelitian dilakukan dengan dua siklus yang memuat aspek perencanaan, tindakan, observasi, dan refleksi. Perencanaan kegiatan penelitian meliputi identifikasi masalah, menyusun rencana pelaksanaan pembelajaran (RPP) untuk setiap kegiatan tindakan, lembar kerja siswa, alat evaluasi dan media, alat dan bahan yang dibutuhkan dalam pembelajaran, serta membentuk kelompok-kelompok yang dilakukan secara acak. 
Pelaksanaan tindakan (acting) meliputi kegiatan pendahuluan, inti dan penutup. Observasi terhadap kegiatan belajar dilakukan pada saat pelaksanaan kegiatan belajar mengajar untuk mengetahui jalannya proses pembelajaran. Pada akhir siklus diakhiri dengan tes. Berdasarkan hasil observasi dan hasil tes, maka tahap berikutnya dapat dilaksanakan. Data yang dikumpulkan dari hasil observasi meliputi data hasil belajar, data proses pembelajaran di kelas, dan data observasi dari penyelesaian lembar kerja siswa dalam melihat kemampuan matematis siswa.

Refleksi dalam penelitian tindakan kelas ini merupakan upaya untuk mengkaji apa yang telah terjadi, atau yang belum tuntas pada langkah atau upaya sebelumnya. Hasil refleksi itu digunakan untuk mengambil langkah lebih lanjut dalam upaya untuk mencapai tujuan penelitian. Data yang diperoleh dari hasil observasi, dianalisis dan dievaluasi bersama guru observer. Hasil temuan yang mungkin masih belum maksimal dilakukan, perlu mendapat perhatian untuk pertemuan berikutnya. Kegiatan refleksi diantaranya adalah mengetahui jumlah prosentase siswa yang memiliki nilai dibawah KKM, kendala-kendala yang dialami siswa dan guru serta kemungkinan meningkatkan tingkat pemahaman.

\section{HASIL}

\section{Kondisi Awal}

Sebelum dimulainya penelitaian, pembelajaran yang dilakukan hanya menggunakan metode ceramah dan hanya sesekali menggunakan metode diskusi. Guru lebih sering menjelaskan seluruh materi secara lisan tanpa menggunakan model pembelajaran lain, alat peraga, dan software yang digunakan dalam matematika yang dapat membangkitkan minat belajar siswa. Minat siswa yang kurang terhadap pembelajaran matematika mengakibatkan siswa kurang aktif dalam proses belajar. Kurang aktifnya siswa disebabkan siswa hanya mendengarkan tanpa secara aktif dilibatkan dalam proses belajar. Siswa hanya mencatat tanpa banyak bertanya sehingga tidak diketahui tingkat pemahamannya. Pada akhir pembelajaran setiap materi dilakukan tes dan hasilnya banyak siswa yang nilainya dibawah KKM terlihat pada grafik 1 berikut ini:

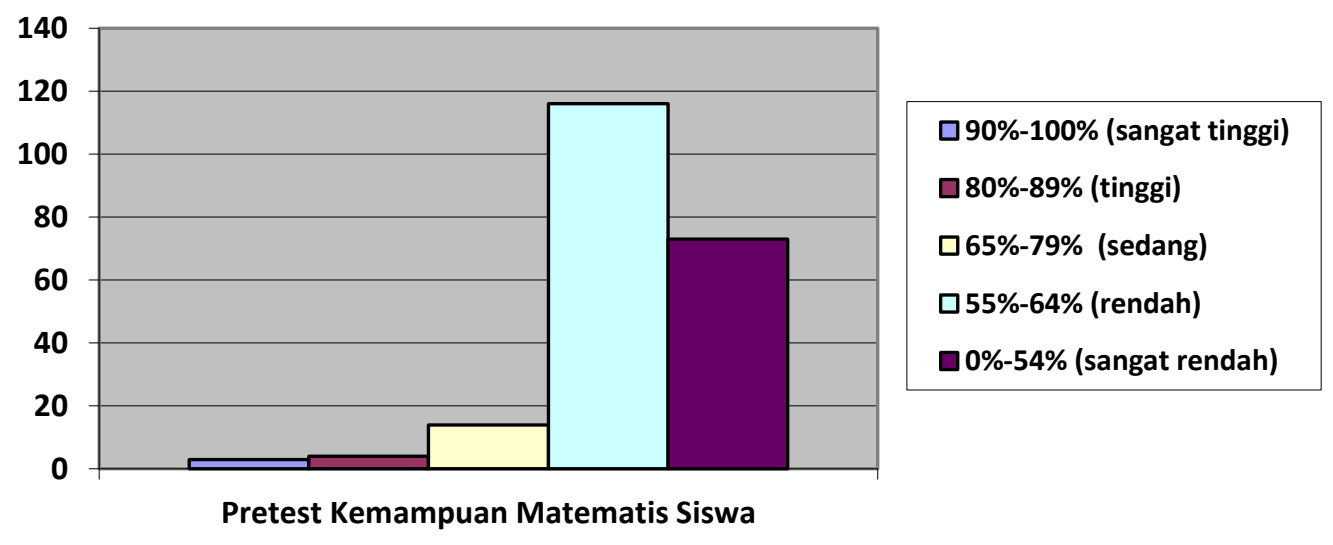

Grafik 1. Pretest Kemampuan Matematis Siswa 
Hal diatas disebabkan karena siswa lebih banyak menghafalkan materi sehingga kebanyakan siswa tidak mampu dalam menyelesaikan soal matematika dengan benar. Pembelajaran dengan menggunakan bantuan software geogebra akan lebih mudah bagi siswa dalam menyelesaikan soal geometri. Penemuan konsep geometri pada tahun sebelumnya lebih banyak dilakukan dengan manual. Penerapan model ceramah dirasakan kurang menarik minat dan keaktifan siswa. Dengan demikian pembelajaran belum memenuhi standar yang diinginkan maka diperlukan langkah perbaikan.

Hasil belajar kemampuan matematis siswa yang tuntas sebanyak 21 siswa dari 210 siswa (10\%), sedangkan 189 siswa lainnya (90\%) belum mencapai KKM. Pada grafik 1 terlihat hasil ulangan harian berbanding lurus dengan kemampuan matematis siswa dalam proses pembelajaran. Hasil belajar akan meningkat jika siswa diajarkan dengan menggunakan software geogebra dalam proses pembelajaran materi geometri.

\section{Deskripsi Penelitian Pada Siklus I}

Setelah tindakan pembelajaran yang dilakukan pada siklus I, peneliti mengidentifikasi permasalahan yang ditemukan selama pembelajaran tersebut. Berdasarkan hasil obeservasi dan peneliti amati selama pembelajaran maka diperoleh beberapa hal-hal yang diperhatikan oleh peneliti sehingga menjadi bahan perbaikan untuk siklus berikutnya yaitu:

a) Siswa kurang memahami dalam penggunakan software geogebra setelah dilakukan pengajaran pada siklus I dengan demikian perlu dilakukan kembali pengajaran menggunakan software geogebra, sehingga siswa mampu menyelesaikan soal geogebra dengan benar.

b) Kemampuan matematis siswa dalam menyelesaikan soal-soal pada siklus I yang belum mencapai tingkat ketuntasan sebanyak 97 siswa atau 46,19\%, sedangkan siswa yang telah mencapai tingkat ketuntasan sebanyak 113 siswa atau 53,81\%. Dengan demikian dapat dikatakan kelas tersebut belum tuntas dalam menyelesaikan soal geometri yaitu belum terdapat $\geq 80 \%$ siswa yang memiliki tingkat ketuntasan kemampuan matematis pada siklus I. Dibawah ini grafik 2 memperlihatkan kemampuan matematis siswa pada siklus I sebagai berikut:

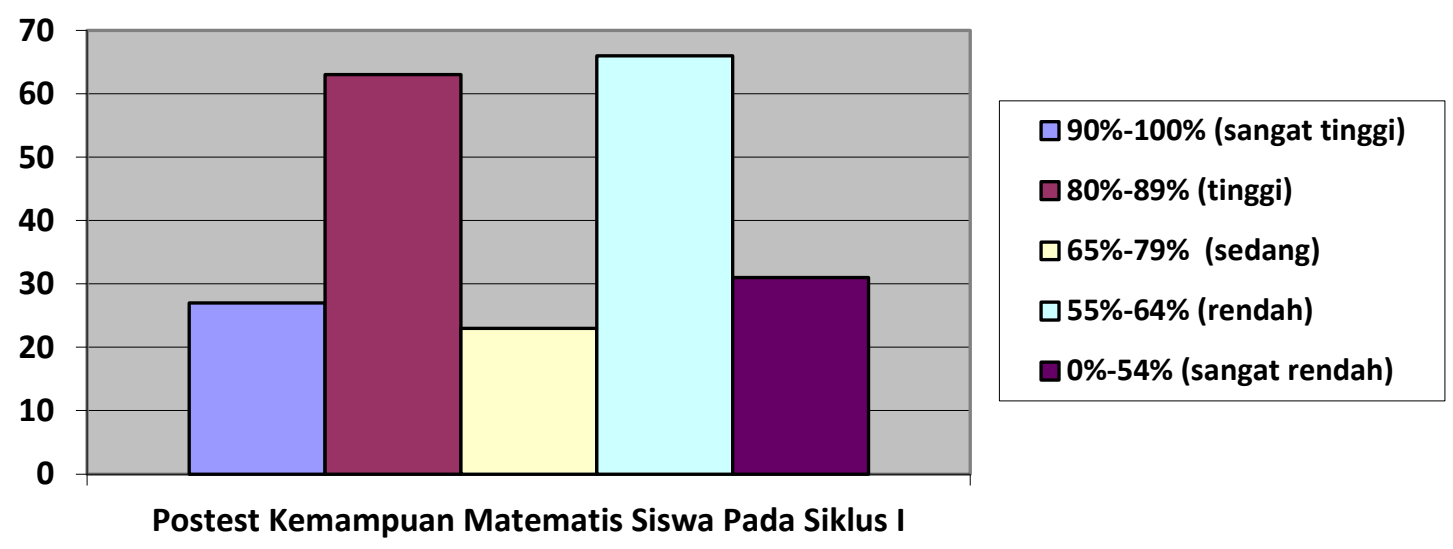

Grafik 2. Kemampuan Matematis Siswa Pada Siklus I 


\section{Deskripsi Penelitian Pada Siklus II}

Setelah dilanjutkan tindakan pembelajaran yang dilakukan pada siklus II kemampuan matematis siswa meningkat dari sebelumnya. Hal ini dapat dilihat dari:

a) Kemampuan matematis siswa dalam menyelesaikan soal-soal pada siklus II dengan tingkat kemampuan sangat tinggi sebanyak 35 siswa atau 16,67\%, tingkat kemampuan tinggi sebanyak 46 siswa atau 21,90\%, tingkat kemampuan sedang sebanyak 98 siswa atau 46,67\%, tingkat kemampuan rendah sebanyak 16 siswa atau 7,62\%, dan tingkat kemampuan sangat rendah sebanyak 15 siswa atau 7,14\%. Sedangkan siswa yang telah mencapai tingkat ketuntasan sebanyak 179 siswa atau 85,24\%. Dengan demikian dapat dikatakan rata-rata siswa kelas IX telah tuntas dalam menyelesaikan soal geometri yaitu terdapat $\geq 80 \%$ siswa yang memiliki tingkat ketuntasan kemampuan matematis pada siklus II dapat dilihat pada grafik dibawah ini:

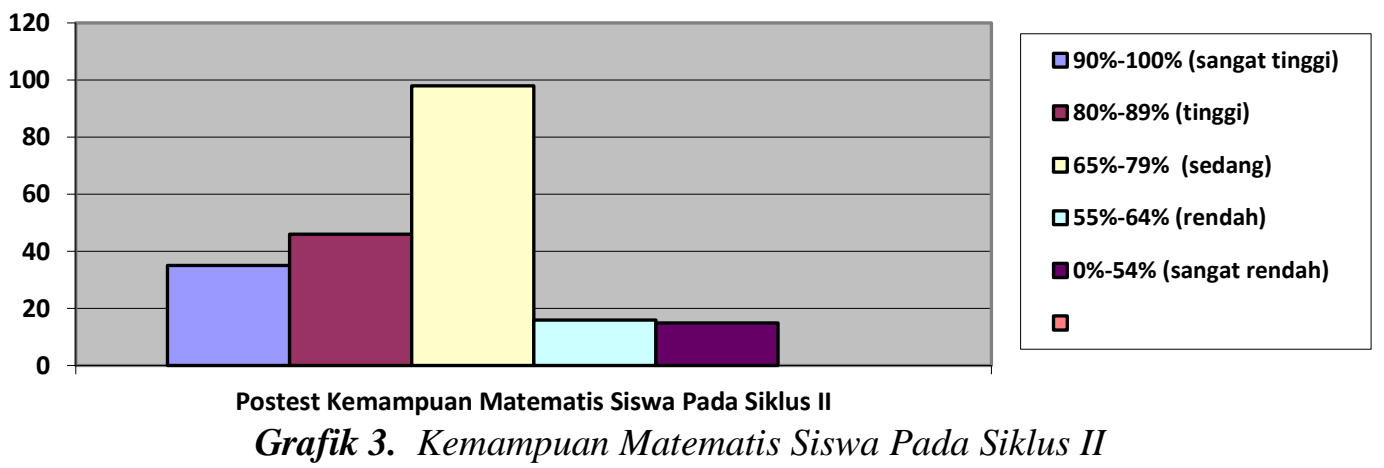

b) Dari grafik 3 diatas ada pertambahan jumlah siswa yang mencapai tingkat ketuntas diperoleh dari tes kemampuan matematis siswa pada materi geometri menggunakan software geogebra pada siklus II adalah 85,24\%, sedangkan pada tes kemampuan matematis siswa pada materi geometri menggunakan software geogebra pada siklus I tingkat ketuntasan kemampuan matematis siswa diperoleh sebesar $53,81 \%$. Jadi diperoleh peningkatan ketuntasan kemampuan matematis siswa dari siklus I ke siklus II sebesar 31,43\%.

Beberapa siswa masih belum mampu dalam menyelesaikan soal-soal yang diberikan, akan tetapi jumlah siswa yang belum mampu menyelesaikan soal sudah berkurang dari sebelumnya. Hal ini dapat diketahui dari hasil tes kemampuan matematis siswa pada siklus II. Berdasarkan hasil analisis data dapat ditarik kesimpulan bahwa kemampuan matematis siswa mengalami peningkatan dan siswa telah mencapai tingkat ketuntasan belajar yang diharapkan. Hal ini menunjukkan keberhasilan pembelajaran tidakan pada siklus II.

Berdasarkan uraian di atas, dari kondisi awal ke kondisi akhir pada siklus II banyak peserta didik yang aktif dalam mengikuti proses pembelajaran dikarenakan penggunaan aplikasi geogebra dalam menyelesaikan soal geometri. Kemampuan siswa dalam pembelajaran geometri dengan menggunakan software Geogebra mengalami peningkatan. Siswa juga menyatakan bahwa pembelajaran geometri dengan menggunakan sotware tersebut menjadi lebih menyenangkan sehingga 
mereka dapat lebih memahami pembelajarannya tanpa sekedar menghapal. Berikut contoh salah satu hasil kerja siswa dengan menggunakan software Geogebra dalam topik pembelajaran rotasi geometri:

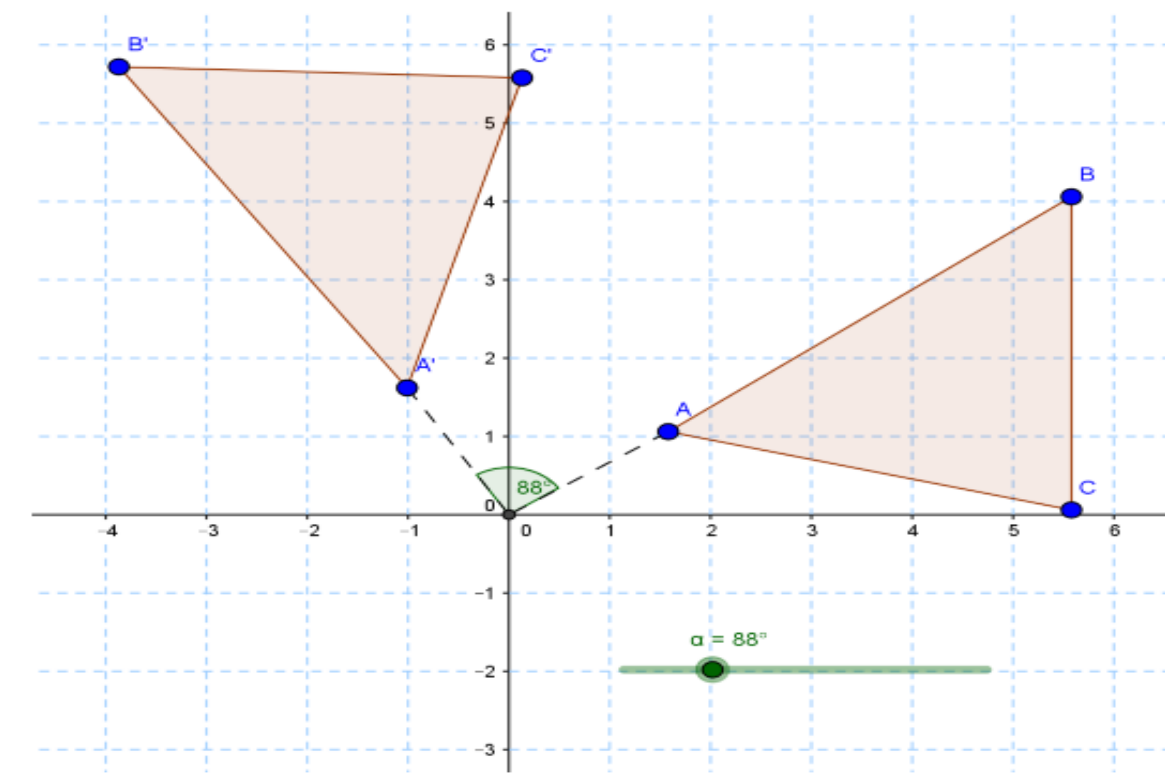

Gambar 2. Contoh Hasil Kerja Siswa dalam Pembelajaran Rotasi Geometri dengan Menggunakan Software Geogebra

Walaupun ditemukan peningkatan hasil belajar matematis siswa dalam pembelajaran geometri dengan menggunakan software Geogebra, namun ditemukan pula kekurangan Geogebra dalam pembelajaran matematika. Kekurangan ini terutama dirasakan oleh para siswa. Dikarenakan tidak semua siswa memiliki komputer ataupun laptop sehingga penggunaan Geogebra ini akan kurang maksimal. Siswa yang tidak memiliki komputer dan laptop tidak akan dapat mempelajari kembali dirumah.

\section{KESIMPULAN}

Berdasarkan hasil penelitian dan pembahasan diperoleh simpulan bahwa: Pembelajaran dengan menggunakan software Geogebra dapat meningkatkan kemampuan matematis siswa dan jumlah siswa yang telah mencapai KKM pada materi geometri setelah menggunakan software geogebra dari kondisi awal ke siklus I dan siklus I ke siklus II meningkat. Oleh karena itu, software geogebra dapat digunakan dalam proses pembelajaran pada pokok bahasan geometri maupun mata pelajaran lain yang mempunyai karakteristik yang sama.

\section{DAFTAR PUSTAKA}

Adelabu, F. M., Makgato, M., \& Ramaligela, M. S. (2019). The Importance of Dynamic Geometry Computer Software on Learners' Performance in Geometry. Electronic Journal of E-Learning, 17(1), 52-63.

Bawono, E. (2015). Pengaruh Metode Accelerated Learning Berbantu Jurnal Belajar dan Geogebra 3d 
Ditinjau dari Kemampuan Pemahaman Matematik terhadap Hasil Belajar pada Ruang Dimensi Tiga. Aksioma: Jurnal Matematika Dan Pendidikan Matematika UPGRIS Semarang, 3(1), 6977.

Dahal, N., \& Thapa, R. (2019). Use of Geogebra for Teaching and Learning Geometry (Circle): Initiation for Quality Education. Second International Conference on Quality Education., August.

Ekawati, A. (2016). Penggunaan Software Geogebra Dan Microsoft Mathematic dalam Pembelajaran Matematika. Jurnal Pendidikan Matematika, 2(3), 148-153.

Japa, N., Suarjana, I. M., \& Widiana, W. (2017). Media Geogebra Dalam Pembelajaran Matematika. International Journal of Natural Science and Engineering, 1(2), 40-47.

Peraturan Menteri Pendidikan Nasional Republik Indonesia Nomor 16 Tahun 2007, 1 (2007).

Muqtada, M. R., Irawati, S., \& Qohar, A. (2018). Reciprocal Teaching assisted by GeoGebra to Improve Students Mathematical Communication. Jurnal Pendidikan Sains, 6(4), 238-246.

Pamungkas, M. D., Rahmawati, F., \& Dinara, H. A. (2020). Integrating GeoGebra into Space Geometry in College. 3rd International Conference on Learning Innovation and Quality Education (ICLIQE 2019), 397, 999-1006.

Safrida, L. N., Susanto, S., \& Ambarwati, R. (2018). Integrating GeoGebra into Geometry Learning : A Lesson from Traditional Osing House Structures. International Conference on Mathematical Analysis, Its Applications and Learning 2018, September 2018, 88-94.

Saputra, E., \& Fahrizal, E. (2019). The Development of Mathematics Teaching Materials through Geogebra Software to Improve Learning Independence. Malikussaleh Journal of Mathematics Learning (MJML), 2(2), 39-44.

Saputro, B. A. (2016). Learning Media Development Approach With a Rectangle Problem Posing Based Geogebra. Infinity Journal, 5(2), 121.

Sari, P., Hadiyan, A., \& Antari, D. (2018). Exploring Derivatives by Means of GeoGebra. International Journal on Emerging Mathematics Education, 2(1), 65. 